a debate ¿el patrimonio cultural en crisis? ¿y ahora qué? | coordina Gabriel Morate Martín

\title{
¿Crisis, qué crisis?
}

José Antonio Ruiz Gil | Área de Prehistoria, Dpto. de Historia, Geografía y Filosofía, Universidad de Cádiz

URL de la contribución <www.iaph.es/revistaph/index.php/revistaph/article/view/3419>

Quiero aprovechar esta ocasión para refrescar algunas ideas que ya hace tiempo he publicado. Para comenzar este razonamiento, que no puede ser excesivamente extenso, he de convenir con el espíritu impulsor de las preguntas que el editor hacía, a fin de dar entidad al tema del debate: la realidad económica del patrimonio. Por tanto, mi axioma será justamente ese, que el patrimonio "se dice" (como el "ser" aristotélico) de muchas maneras, una de ellas es la económica.

¿Es esta faceta económica la más relevante? Esta es la cuestión, maximizada por los tiempos que corren. Pero, en mi opinión, tal emergencia histórica carece de sentido. Parafraseando a Supertramp, me pregunto ¿Crisis, qué crisis? Porque en nuestra materia, en el universo patrimonial siempre ha habido crisis. Sobre todo tratándose del espacio que ocupamos: Andalucía. No hay más que ver o leer textos de biblioteca o de hemeroteca desde los años ochenta del pasado siglo (RUIZ GIL, 2005).

Exista recesión económica o no, la justificación de las inversiones, de modo general, radica en el beneficio, social o económico, que produzcan. Por tanto, cuando nos preguntamos sobre tal circunstancia específicamente en patrimonio cultural, hemos de sospechar sobre el fundamento ético de la cuestión. Cosa que no podemos hacer sin tocar otra de las cuestiones clave, cual es la relación entre lo público y lo privado, lo necesario y lo accesorio, de las cuentas públicas.

Simplemente recordar al lector que partimos de un modelo de planificación (los Planes Generales de Bienes Culturales) y que estamos, a tontas y a locas, en una huida hacia un horizonte de participación financiera privada que parece conocerse como el Pacto por la Cultura en Andalucía, cuyo máximo exponente hasta el momento es el anteproyecto de ley de mecenazgo andaluza. Llegados a este punto es cuando nos cuestionamos no sólo el motivo, sino el transcurso, de tal decisión política.
Estamos inmersos en un modelo altamente intervencionista en el que la eficacia es un concepto secundario. El mantenimiento a ultranza de las que podemos llamar "banderas de nuestros padres" implica un exceso en el mantenimiento de las estructuras de política cultural en detrimento de las inversiones; toda vez la inexistencia de nuevas formas de organización y de racionalización de los gastos sobre la base del concepto de eficacia. Una eficacia donde la sociedad civil pueda ejercer de contrapoder en ese ficticio discurso entre lo público y lo privado. El patrimonio es social, su gestión es la que se puede hacer pública o privadamente.

En un momento tan crítico como el actual es lógico que surjan voces que soliciten un papel protagonista para el patrimonio con respecto al desarrollo económico y a la creación de empleo. Pero esta lógica es la heredera de los sistemas de "monocultivo" que nos han llevado, en parte, al lugar en el que estamos. Es un canto de sirenas. Y no debemos dejarnos llevar por los cantos de sirenas, como los que pretenden hacer de nuestra Comunidad un lugar único para el turismo, lugar donde ubicar al patrimonio. Recordemos que esto es lo que se hizo con el sector del llamado ladrillo. No es un problema de suplir la financiación cesante, sino de cambiar un modelo que sólo funciona consumiendo grandes cantidades de recursos.

Sólo la reflexión, la investigación, la mesura, y la participación ciudadana (social) pueden hacer un sector sólido en materia de patrimonio cultural. Y el poder público democrático ha de estar justamente para conseguir, mediante el Derecho, un justo y equilibrado reparto de cargas y beneficios

\section{BIBLIOGRAFIA}

- RUIZ GIL, J. A. (2005) Creer y Crear. El Patrimonio Cultural en la encrucijada de la Globalización. Cádiz: Universidad de Cádiz, Servicio de Publicaciones, 2005 